\title{
PENGAWASAN PEMERINTAH TERHADAP PELAKSANAAN PROGRAM PEMBAGIAAN ALAT TANGKAP DI KECAMATAN BISSAPPU KABUPATEN BANTAENG
}

\author{
Jufri $^{1}$, Alimuddin Said ${ }^{2}$, Samsir Rahim ${ }^{3}$ \\ 1) Ilmu Administrasi Negara Unismuh Makassar \\ 2) Ilmu Administrasi Negara Unismuh Makassar \\ 3) Ilmu Administrasi Negara Unismuh Makassar
}

\begin{abstract}
ABSTRACK
The purpose of this was to find out how the geverment supervision on the implementation of fishing gear program in Bissappu district Bantaeng regency as well as to know the factors that influenced the supervision of the implementation in the district. Type of research was qualitative. This study used case study type. Date collection techiniques used in the form of questionnaires. Observation and documentation. The result of this study indicated that the supervision carried ouy by the geverment was monitoring and controlling and there was a significant influence between the government supervision on the program of distribution of fishing gear in Bissappu District Bantaeng regency. Goverment supervion was strongly influenced by leadership, effectiveness and welfare.
\end{abstract}

Keywords: Government Supervision, Community Empowerment, and Welfare Improment

\begin{abstract}
ABSTACK
Tujuan penelitian ini adalah untuk mengetahui bagaimana pengawasan pemerintaah terhadap pelaksanaaan program aalat tangkap ikan di Kecamataan Bissappu Kabupaten Bantaeng serta untuk mengetahui factor-faktor yang mempengaruhi pengawasan pemerintah terhadap pelaksanan dikecaamatan tersebut. Jenis penelitian adalah kualitatif. Penelitian ini menggunakan type study kasus. Teknik pengumpulan data instrument berupa Observasi, wawancara dan dokumentasi. Hasil penelitian ini menunjukkan bahwa pengwasan yang dilakukan pemerintah adalah pemantauan dan pengontrolan sert adanya pengaruh yang signifikan anata pengawasan permerintah terhadap pelaksanaan program pembagiaan alat tangkap ikan di Kecamatan Bissappu Kabupaten Bantaeng. Pengawasan pemerintah sangat dipengaruhi oleh factor kepemimpinan, efektivitas dan tingkat kesejahteraan.
\end{abstract}

Kata Kunci: Pengawasan Pemerintah, Pemberdayaan Masyarakat dan peningkatan kesejahteraan 


\section{PENDAHULUAN}

Sesuai dengan Peraturan bersama guna meningkatkan Menteri Perikanan dan Kelautan RI pendapatan anggota.

Nomor PER. 02/MEN/2011 tanggal 31

januari 2011 tentang Jalur

Penangkapan Ikan dan Penempatan

Alat Penangkapan Ikan dan Alat bantu

Penangkapan Ikan di Wilayah

Pengelolaan Perikanan Republik

Indonesia.

Sasaran utama program PUMP

ini, yaitu dengan terbentuknya Kelompok Usaha Bersama (KUB).

KUB adalah badan usaha non badan hukum ataupun yang sudah berbadan hukum yang berupa kelompok yang dibentuk oleh nelayan berdasarkan hasil kesepakatan/musyawarah seluruh anggota yang dilandasi oleh keinginan bersama untuk berusaha bersama dan di pertanggungjawabkan secara

\section{Dengan dibentuknya KUB} dikelurahan ini, tentunya menjadi satu langkah baru dalam masyarakat nelayan mengembangkan kesejahteraan hidupnya secara mandiri. Kondisi masyarakat nelayan didaerah ini memang perlu diperhatikan mengingat sebagian besar masyarakat menggantungkan hidupnya dari penghasilan laut.

Salah satunya adalah Program Pembagiaan Alat Tangkap Ikan nelayan (jaring) yang bertujuan meningkatkan kesejahteraan dan kesempatan kerja masyarakat miskin secara mandiri. Namun melihat kenyataan yang terjadi yaitu kurangnya pengawasan pemerintah dalam memberikan arahan kepada 
masyarakat yang harusnya musyawarah mufakat oleh lembaga mendapatkan bantuan tersebut agar masyarakat.Program Pembagiaan Alat tercipta masyarakat yang baik dan Tangkap Ikan (jaring) harus banyak terbina demi generasi melibatkan warga masyarakat sebagai selanjutnya.Pemerintah menganggap pelakudalamlembaga pemerintahan bahwa Kabupaten Bantaeng sebagai agar generasi selanjutnya bisa perangkat daerah teratas yang mendapatkan bantuan dan bersentuhan langsung dengan menggunkan bantuan tersebut sebaikmasyarakat perlu mendapatperhatian baiknya namun kurangnya pengawasan lebih dalam pendistribusian pemerintah terhadap program kewenangan terutama yang pembagian ini mengakibatkan berkaitandengan pembangunan masyarakat tidak mandiri di wilayahnya yang membayar kembali serta banyak yang melibatkan langsung masyarakatnya menghambat selama pelaksanaan. baik secara individu maupun Maka dari itu penulis ingin kelembagaan. meneliti mengenai pengawasan Bantuan Langsung Masyarakat pemerintah dalam pelaksanaan untuk memacu kegiatan pembangunan program pembagiaan alat tangkap dan baik fisikmaupun non-fisik yang faktor-faktor yang mempengaruhi dilaksanakan oleh masyarakat itu pengawasan selama pelaksanaan sendiri secara mandiri, yang pembagiaan program PUMP. sebelumnya telah direncanakan secara 
Pengawasan merupakan fungsi

manajemen yang sangat berkaitan erat denganpencapaian tujuan organisasi, sehingga pengawasan dalam organisasi apapunmenjadi mutlak dilakukan. Hal ini seperti yang diungkapkan oleh G.R. Terry, yang mengatakan bahwa: "Dalam rangka pencapaian tujuan suatu organisasi,termasuk negara sebagai organisasi kekuasaan terbesar seyogyanya menjalankan fungsi-fungsi manajemen yang terdiri dari: perencanaan (planning),

pengorganisasian (organizing), memberi dorongan (actuating), dan pengawasan (controlling)." (G.R Terry, 1991:15)

$$
\text { Menurutnya, pengawasan }
$$

sebagai upaya kontrol birokrasi ataupun organisasi harus dilaksanakan dengan baik, karena: "Apabila tidak dilaksanakan, cepat atau lambat akan mengakibatkan mati/hancurnya suatu organisasi atau birokrasi itu sendiri." (Terry, 1991:137)Hal tersebut juga didukung oleh Victor Situmorang dalam bukunya Aspek Hukum

Pengawasan Melekat dalam Lingkungan Aparatur Pemerintah, yang mengatakan bahwa: "Sebagai salah satu fungsi manajemen, mekanisme pengawasan suatu organisasi memang mutlak diperlukan. Pelaksanaan suatu rencana dan program tanpa diiringi dengan suatu sistem pengawasan yang intensif dan berkesinambungan jelas akan mengakibatkan lambatnya, atau bahkan tidak tercapainya sasaran dan tujuan yang telah ditentukan.” (Situmorang, 1994:8) Pendapat yang sama juga dikemukakan oleh Mc. Farland seperti yang dikutip Handayaningrat sebagai 
berikut: "Control is the process by which an executivegets the performance of his subordinate to correspond as closely as posible tochosen plans, orders, objectives, or policies. (Pengawasan ialah suatu proses dimana pimpinan ingin mengetahui apakah hasil pelaksanaan pekerjaan yang dilakukan oleh bawahannya sesuai dengan rencana, perintah, tujuan atau kebijaksanaan yang telah ditentukan).” (Handayaningrat, 1985:143)

Jadi pengawasan penting untuk dilaksanakan, mengingat pengawasan tersebut dapat mempengaruhi hidup/matinya suatu organisasi atau birokrasi, dan untuk melihat apakah pelaksanaan pekerjaan telah sesuai dengan rencana, perintah, tujuan, dan kebijaksanaan dalam upaya mencapai tujuan yang telah ditetapkan.
Pengawasan itu sendiri didefinisikan oleh Sujamto dalam bukunya Aspek-aspek Pengawasan di Indonesia sebagai: "Segala usaha atau kegiatan untuk mengetahui dan menilai kenyataan yang sebenarnya tentang pelaksanaan tugas atau pekerjaan, Apakah sesuai dengan yang semestinya atau tidak." (Sujamto, 1987:53) Senada dengan pendapat diatas, M. Manulang dalam karyanya Dasar-dasar Manajemen, mendefinisikan pengawasan sebagai: "Suatu proses untuk menetapkan pekerjaan apa yang sudah dilaksanakan, menilainya, dan mengoreksinya bila perlu dengan maksud supaya pelaksanaan pekerjaan sesuai dengan rencana semula." (H. Bohari, 1992:4)

Kedua pendapat tersebut diperkuat lagi oleh pernyataan 
Sondang P. Siagian dalam bukunya

Filsafat Administrasi, yang

menyatakan bahwa pengawasan adalah

:"Proses pengamatan daripada

pelaksanaan seluruh organisasi untuk

menjamin agar semua pekerjaan yang

sedang dilakukan berjalan sesuai

dengan rencana yangtelah ditetapkan.”

(Siagian, 1984:135). Berdasarkan

pendapat-pendapat di atas, maka

secara singkat inti dari definisi

pengawasan adalah usaha untuk

menjamin agar pelaksanaan sesuai

dengan rencana yang telah ditentukan

dan disepakati bersama. Lebih rinci

lagi, Kaho mendefinisikan pengawasan

sebagai: "Suatu usaha sistematik untuk

menerapkan standar pelaksanaan

dengan tujuan perencanaan,

merancang sistem informasi umpan

balik, membandingkan kegiatan nyata

dengan standar yang telah ditetapkan sebelumnya, menentukan dan

mengukur penyimpangan-

penyimpangan, serta mengambil

tindakan-tindakan koreksi yang

diperlukan untuk menjamin bahwa

semua sumber daya organisasi

dipergunakan dengan cara paling

efisien dalam mencapai tujuan-tujuan

yang telah ditentukan.”(Kaho,

1997:239)

\section{METODE PENELITIAN}

Penelitian telah dilaksanakan

selama 2 bulan setelah pelaksanaan

seminar proposal. Lokasi penelitian di

Kecamatan Bissappu Kabupaten

Bantaeng.Yang terdiri dari pesisir

Kabupaten Bantaeng yaitu Kampung

Pesisir tanganga-tanganga, cabodo dan

kaili serta Penelitian telah

dilaksanakan di Kantor Dinas

Perikanan dan Kelautan. Masyarakat

yang terkait pada PUMP dan lokasi 
tersebut mudah dijangkau oleh peneliti.

Jenis penelitian yang digunakan adalah metode penelitian kuliatatif yang berusaha menjelaskan sedetail mungkin objek dan masalah penelitian berdasarkan fakta yang diperoleh di lapangan. Metode penelitian kulitatif sebagai prosedur yang menghasilkan data deskriptif berupa fakta-fakta tertulis atau lisan dari orang-orang dan perilaku yang dapat diamati. Informan penelitian Kabid Usaha Penangkapan, Penyuluh Perikanan, dan masyarakat kelompok KUB.

\section{HASIL DAN PEMBAHASAN}

Kabupaten Bantaeng adalah sebuah Kabupaten di Provinsi Sulawesi Selatan, Indonesia. Terletak dibagian Selatan Provinsi Sulawesi Selatan. Kabupaten ini memiliki luas wilayah $395,83 \mathrm{~km}^{2}$ atau $39.583 \mathrm{Ha}$ yang dirinci berdasarkan Lahan Sawah mencapai 7.253 Ha $(18,32 \%)$ Ha dan Lahan Kering mencapai 32.330.

Secara administrasi Kabupaten Bantaeng terdiri atas 8 kecamatan yang terbagi atas 21 Kelurahan dan 46 desa. Jumlah penduduk mencapai 170.057 jiwa. Kabupaten Bantaeng terletak di daerah pantai yang memanjang pada bagian barat dan timur sepanjang 21,5 kilometer yang cukup potensial untuk perkembangan perikanan dan rumput laut.
A. Visi dan Misi Kabupaten
Bantaeng 1. Visi

Visi pada prinsipnya adalah gambaran tentang sosok masa depan organisasi yang harus memberi inspirasi dan motivasi semua pihak yang berkepentingan terhadap masa depan organisasi. Oleh karenanya sesuai 
nilai-nilai strategis serta keterkaitan dengan visi Kabupaten maka visi Kabupaten Bantaeng adalah sebagai pusat pertumbuhan ekonomi di Sulawesi Selatan tahun 2018.

\section{Misi}

Misi dimaksudkan sebagai suatu penjabarab misi yang menjadi pedoman komitmen bersama bagi suatu rencana strategis yang berfungsi sebagai standar kerja organisasi, untuk itu misi Kabupaten Bantaeng adalah sebagai berikut :

a. Meningkatkan kualitas sumber daya manusia $\quad(S D M) \quad$ melalui pengembangan kapasitas penduduk.

b. Optimalisasi pemanfaatan sumber daya alam (SDA) bidang pertaniaan dan keluatan.

c. Meningkatkan jaringan perdangan, Industri dan pariwisata. d. Memaksimalkan berkembangnya lembaga ekonomi masyakat secara terpadu.

e. Penguatan kelembagaan pemerintah.

(PUMP) Pengembangan Usaha Mina Perdesaan adalah konsepsi pembangunan ekonomi kelautan dan perikanan berbasis kawasan berdasarkan prinsip-prinsip terintegrasi, efisiensi, berkualitas dan percepatan. Pengembangan Usaha Mina Perdesaan ini juga dicirikan dengan kawasan perikanan yang tumbuh dan berkembang karena berjalannya sistem dan usaha minabisnis yang diharapkan dapat melayani dan mendorong kegiatankegiatan pembangunan perikanan (minabisnis).

Sesuai dengan Keputusan Direktur Jenderal Perikanan Tangkap Nomor 15 Tahun 2011, 
Pengembangan Usaha Mina Perdesaan yang selanjutnya disebut PUMP adalah bagian dari pelaksanaan PNPM Mandiri melalui bantuan modal usaha dalam menumbuh kembangkan usaha perikanan tangkap sesuai dengan potensi sumber daya ikan.

Program Nasional

Pemberdayaan Masyarakat Mandiri

Kelautan dan Perikanan (PNPM Mandiri - KP), PNPM Mandiri adalah program nasional penanggulangan kemiskinan terutama yang berbasis pemberdayaan masyarakat. Pengertian yang terkandung mengenai PNPM Mandiri adalah sebagai berikut :

PNPM Mandiri adalah program nasional dalam wujud kerangka kebijakan sebagai dasar dan acuan pelaksanaan program - program penanggulangan kemiskinan berbasis pemberdayaan masyarakat.PNPM
Mandiri dilaksanakan melalui harmonisasi dan pengembangan sistem serta mekanisme dan prosedur program, penyediaan pendampingan dan pendanaan stimulan untuk mendorong prakarsa dan inovasi

masyarakat dalam upaya penanggulangan kemiskinan yang berkelanjutan.

Program Nasional

Pembedayaan Masyarakat Mandiri Kelautan dan Perikanan (PNPM Mandiri - KP) adalah program pemberdayaan masyarakat bidang kelautan dan perikanan yang ditujukan untuk mengurangi kemiskinan dan meningkatkan kesempatan kerja serta meningkatkan produksi bidang kelautan dan perikanan. PNPM Mandiri-KP secara umum bertujuan untuk meningkatkan kesejahteraan dan kesempatan kerja kelompok 
masyarakat miskin bidang kelautan dan perikanan.

Kehidupan yang didambakan oleh semua manusia di dunia ini adalah kesejahteraan. Baik yang tinggal di kota maupun yang di desa, semua mendambakan kehidupan yang sejahtera. Perjalanan kehidupan yang dijalani oleh manusia tak selamanya dalam kondisi sejahtera.

Di Indonesia kesejahteraan sosial dijamin oleh UUD 1945 pasal 33 dan pasal 34. Dalam UUD 1945 jelas disebutkan bahwa kemakmuran rakyat yang lebih diutamakan dari pada kemakmuran perseorangan, Fakir miskin dan anak-anak terlantar dipelihara oleh negara. Selain itu juga Menurut Undang - undang No 11 Tahun 2009, kesejahteraan Sosial adalah kondisi terpenuhinya kebutuhan material, spiritual, dan sosial warga
Negara Indonesia agar dapat hidup layak dan mampu mengembangkan diri, sehingga dapat melaksanakan fungsi sosialnya.

Istilah kesejahteran sosial sering diartikan sebagai kondisi sejahtera, yaitu suatu keadaan terpenuhinya segala bentuk kebutuhan hidup, khususnya yang bersifat mendasar seperti makanan, pakaian, perumahan, pendidikan dan perawatan kesehatan masyarakat nelayan.

Masyarakat nelayan secara luas adalah sekelompok manusia yang mempunyai mata pencaharian pokok mencari ikan dilaut dan hidup di daerah pantai. Kelurahan adalah pembagian wilayah administratif di Indonesia di bawah kecamatan. Dalam konteks otonomi daerah di Indonesia, Kelurahan merupakan wilayah kerja Lurah sebagai Perangkat Daerah 
Kabupaten atau kota. Kelurahan dipimpin oleh seorang Lurah yang berstatus sebagai Pegawai Negeri Sipil.

Kelurahan merupakan unit pemerintahan terkecil setingkat dengan desa. Berbeda dengan desa, kelurahan memiliki hak mengatur wilayahnya lebih terbatas.Dalam perkembangannya, sebuah desa dapat diubah statusnya menjadi kelurahan. Dalam PP 73 Tahun 2005, dikatakan bahwa Kelurahan adalah wilayah kerja lurah sebagai perangkat Daerah Kabupaten/Kota dalam wilayah kerja Kecamatan.

Pelaksanaan anggaran adalah suatu program atau proyek perhitungan banyaknya biaya yang diperlukan untuk bahan dan upah, serta biayabiaya lain yang berhubungan dengan pelaksanaan program atau proyek.
Maka dari itu berikut ini adalah pelaksanaan anggaran yang dilakukan oleh kelompok cahaya laut yang merupakan landasan dari data kelompok Cahaya Laut.

Berdasarkan surat kelompok usaha bersama (KUB) Cahaya Laut nomor 01/KUB-CL/BTSBSP/BTG/I/2013 tentang permohonan pencairan dana tahap pertama tanggal 19 januari 2013, maka dengan ini kami memberikan rekomendasi pencairan dengan dana sebesar Rp.64.810.000 (enam puluh empat juta delapan ratus sepuluh ribu rupiah) untuk keperluan pembelian bahan alat tangkap dan mesin dengan No. Rek 0275022000 untuk dipergunakan sesuai dengan kebutuhan yang telah direncanakan bersama.

$$
\text { Berdasarkan hasil rapat }
$$
kelompok usaha bersama (KUB) 
Cahaya Laut yang telah dilaksanakan pada hari rabu tanggal 15 bulan januari 2013 sebagaimana terlampir, dengan ini kami memohon agar bapak memberikan rekomendasi untuk pencairan tahap pertama untuk pembelian alat tangkap dan mesin sebanyak Rp. 64.810 .000 (enam puluh empat juta delapan ratus sepuluh ribu rupiah).

Berdasarkan hasil dokumentasi diatas penulis ingin mengetahui tentang pencairan dana secara bertahap pada kelompok usaha bersama (KUB) Cahaya Laut dimana pada tabel 4.6. dibawa ini menjelaskan kebutuhan dan keinginan masyarakat pada tahap pertama yaitu:

Pemberian bantuan unit penangkapan kepada nelayan adalah merupakan langkah yang secara langsung akan dapat meningkatkan pelaksanaan program nelayan. Dengan adanya bantuan unit penangkapan maka pendapatan nelayan tidak lagi tergantung pada bagi hasil yang diperoleh dari pemilik unit penangkapan, tapi langsung dari besarnya nilai penjualan hasil tangkapan yang diperolehnya. Dalam pelaksanaannya, pemberian bantuan tersebut harus memperhatikan beberapa hal sebagai berikut.

Pertama, bantuan tidak diberikan pada perseorangan, tapi pada kelompok nelayan secara tanggung renteng. Hal ini dimaksudkan untuk mewujudkan adanya suatu usaha bersama dimana masing-masing anggota menanggung jika ada kerugian dan sebaliknya memperoleh keuntungan yang sama bila ada hasil. Karena merasa sama- 
sama memiliki maka diharapkan setiap nelayan akan bersungguh-

sunguh dalam menjalankan

usahanya. Dalam pelaksanaannya dapat ditunjuk seseorang yang dianggap mampu untuk bertindak sebagai koordinator atau ketuanya.

Kedua, unit penangkapan yang yang diberikan disesuaikan dengan keinginan dan kebutuhan nelayan. Dengan bantuan unit penangkapan yang sesuai dengan keinginan dan kebutuhan nelayan maka sudah dapat dipastikan bahwa unit penangkapan tersebut sesuai untuk dioperasikan di perairan dimana nelayan biasa melakukan kegiatan penangkapan dan tidak perlu lagi adanya proses untuk penyesuaian karena dirasakan asing oleh nelayan. Yang lebih penting, bahwa rasa memilikinya akan semakin kuat sehingga usaha penangkapan akan dilakukan dengan penuh kesungguhan. Dalam hal ingin memasukkan suatu inovasi baru, dapat dilakukan melalui dialog dari hati ke hati dengan nelayan dan dilakukan secara terbuka.

Ketiga, pengadaan unit penangkapan yang akan diberikan tidak melalui pendekatan proyek. Dengan pendekatan melalui proyek dalam proses pengeadaannya maka dari sisi biaya akan mengalami pembengkakan dibandingkan nilai riel dari unit penangkapan yang diberikan kepada nelayan. Pembekanan biaya terutama terjadi karena biaya-biaya yang harus dikeluarkan dalam rangka memenuhi persyaratan administrasi proyek, pajak yang harus dibayar dan keuntungan bagi pelaksana 
pekerjaan. Selain itu, ada persepsi yang salah dari masyarakat yang menyangkut program pemnberian bantuan dari Pemerintah. Pada umumnya masyarakat memahami bahwa yang disebut sebagai proyek bantuan dari Pemerintah diartikan sebagai sesuatu yang tidak harus kembali dan tidak harus berhasil. Masyarakat menjadi semakin pintar dan paham karena pengalaman yang diperolehnya selama ini.

Akan lebih baik jika mekanisme pemberian bantuan dilakukan dengan melalui Bank, dimana nelayan calon penerima bantuan diarahkan untuk berhubungan dengan Bank dimana dana dari Pemerintah dititipkan. Secara psikologis nelayan akan lebih taat pada saat berhubungan dengan Bank karena memahaminya bahwa unit penangkapan yang diperolehnya berasal dari kredit dan pasti harus dikembalikan.

Namun demikian, prosedur yang berbelit harus dihindarkan agar tidak ada keegganan dari nelayan untuk mengurus ke Bank. Persyaratan adanya jaminan yang harus disediakan nelayan, jelas tidak akan pernah dapat dipenuhi oleh nelayan, dan oleh karenanya perlu ditiadakan.

Keempat, pemberian bantuan unit penangkapan harus disertai dengan pendampingan manajemen. Pendampingan manajemen sangat diperlukan mengingat bahwa selama ini nelayan terbiasa bertindak sebagai pelaksana atau operator saja. Segala kebutuhan 
yang harus dipersiapkan untuk dapat berangkat ke laut tidak pernah terpikirkan karena biasanya disediakan oleh pemilik unit penangkapan. Untuk merubah sikap dan cara berpikir dari operator menjadi pengelola tidaklah mudah dan perlu waktu. Oleh karenanya diperlukan pendampingan manajemen sehingga terjadi proses perubahan secara bertahap.

Kelima, besarnya dana bergulir yang sudah terkumpul bukan menjadi indikator keberhasilan. Apabila besarnya dana bergulir yang terkumpul dijadikan tolok ukur keberhasilan maka akan mendorong petugas yang ada di lapangan untuk secara ketat menagih dana bergulir pada nelayan setiap kali menjual hasil tangkapan. Petugas lapangan tidak mau dinilai gagal dalam melaksanakan tugasnya. Di sisi lain, tujuan dari program yang dilaksanakan adalah untuk meningkatkan pendapatan nelayan, sehingga akan dinilai berhasil jika pendapatan nelayan meningkat sebagai akibat dari pemberian bantuan unit penangkapan. 


\section{DAFTAR PUSTAKA}

Bohari.1992. Pengantar Ilmu Administrasi dan Manajemen. PT Gramedia : Jakarta

George. 1991. Dasar-dasar Manajemen

Handayaningrat, Soewarno. 1986. Pengantar Studi Ilmu Adminstrasi dan Manajemen. Jakarta: CV Haji Masagung.

Kaho, Josef Riwu. 1997. Prospek Otonomi Daerah di Negara RI. Jakarta: Raja Grafindo Persada.

Siagian, S.P. 1984. Filsafat Administrasi.Jakarta; Gunung Agung.

Sujamto, 1987.Beberapa Pengertian di Bidang Pengawasan. Jakarta: Ghalia Indonesia.

Sujamto. 1996. Aspek-aspek Pengawasan di Indonesia. Jakarta: Ghalia Indonesia.

Situmorang, Juhir. 1994. Hukum Adminstrasi di Daerah. Jakarta: SinarGrafika.

Soewarno. 1986. Pengantar Studi Ilmu Administrsi dan Manajemen. Jakarta: Ghalia Indonesia.

Terry, R, George 1991.Dasar-dasar Manajemen, Bumi Aksara : Jakarta 